Polina M. Stepanova

PhD in Art History, Associate Professor

Professor of Drama and Film Studies Department

St. Petersburg State Institute of Film and Television

e-mail: st-more@yandex.ru

Saint Petersburg, Russia

ORCID 0000-0001-8410-9086

DOI: 10.36340/2071-6818-2021-17-2-124-137

\title{
REACTUALISATION OF THE RITUAL STRUCTURE IN THE PERFORMANCE OF JERZY GROTOWSKI'S SHAKUNTALA BY KALIDASA (1960)
}

Summary: The famous Polish experimental director, Jerzy Grotowski, made an invaluable contribution to the development of the world modern theatrical process. His search during the theatrical (1959-1969) and paratheatrical (1970-1979) periods acutely raised the problem of the relationship between the actor and the audience in the process of creating and perceiving a performance or ritual... Grotowski's discoveries expanded and deepened the subject of the theatre, actualised the philosophy of perception of the field of joint action by the viewer-participant and the actor-creator. The article examines the fundamental foundations of the reconstruction of ritual structures and space in the earliest work of the Polish experimenter. On the example of the play Shakuntala based on the text of the classic Sanskrit drama by Kalidasa (1960), the main methods of working on new connections between the actor and the audience in the course of theatrical performance as a ritual form of complicity are examined. At this stage of the director's work, the primary expressive means are: deconstruction of the stage space, freedom from a clear division into the stage and the audience this allows the viewer to be included in the process of theatrical performance, makes him or her an active participant in the action; a specific selection of material for the production, a classic Indian text that simultaneous-

The famous Polish experimental director, Jerzy Grotowski, comprehending the results of the first period of his work, which lasted ten years from 1959 to 1969 and included all the theatrical works of the director, called this time "a return to ritual" ${ }^{1}$, the recreation of the "participation ceremony" ${ }^{2}$, entry into

1. Grotowski E. "Theater and ritual" // From Poor Theater to ArtGuide. Moscow: Artist. Rejisser. Teater, 2003. P. 100.

2. Ibid p. 101 ly arouses irony in the director, actors and viewers, and at the same time refers to the story of eternal love at the archetypal level; the use of children's drawings in the process of creating stage costumes as a kind of fetishisation of ritual time and space; creation of a unique bodily score of actors to achieve maximum penetration into the problems of the text and at the same time exclusion from it. The central figure in the production is the actor who, without penetrating the stage image at the level of the psychological score of the role, using a mode of existence close to the theatrical systems of V. Meyerhold and $B$. Brecht, creates the score of the role, combining bodily techniques of life (M. Moss) and gesture in metaphysical dimension (M. Jousse). The performer's body acquires the functions of a conductor, creates a new type of communicative model of actor-viewer relations, reveals the dichotomy of visual mise-en-scene solution and the verbal textual part of the performance. Owing to the use of Indian sign systems, the traditional theatrical performance connects with the prototype of the ritual structure that is being created here and now in the living process of the action.

Keywords: ritual structure, bodily techniques, Sanskrit drama, anthropology of gesture, paratheatrical experiences, viewer-participant.

"confrontation with one's own roots" 3 . The choice of dramatic material for early performances determined the director's movement from the traditional theatrical performance to the completely new function of the paratheatrical experiments created by Grotowski in the 1970s, and to the philosophy of mundane ritual performance of the 1980s and 1990s.

3. Ibid p. 111 
The ancient Indian text of the classical Sanskrit drama of the 5th century became a unique transition from works with classical dramatic material of the European and Russian theatrical heritage to texts close to the origins of world theatrical culture. Orpheus by J. Cocteau (1959), Cain by J. Byron (1960), and Mystery-Buff by V. Mayakovsky (1960) were the first experimental performances of the Theater of 13 Rows in the small Polish town of Opole. However, after the staging of Shakuntala based on the Kalidasa text, a qualitative change took place in the repertoire policy of Grotowski's collective, and the pathos of returning to the ritual began to transform into the idea of "confrontation with one's own roots". The collision with the eastern dramatic structure became a catalyst in forming the philosophy of the search for a new form of theatrical performance, in which the audience and actors became accomplices in a single action. Immediately after the work on the embodiment of the Kalidasa text, the collective of the Theater of 13 Rows began a period based on traditional national drama, imbued with the Polish self and carrying folk cultural tradition in the structure of the texts. Such performances as Dziady by A. Mickiewicz (1961), Cordian by Y. Slovatsky (1962), Acropolis by S. Wyspianski (1962) made the theatre one of the most famous experimental sites in the world of the second half of the 20th century.

Working with Indian material revealed and exposed the problem of creating a single informational, sensory, energy field for the actor and the viewer, which was most important for Grotowski in all periods of his work. The search for theatre as "a dialogue with the public", the search for a specific form of this "dialogue" 4 attracted the director from his very first theoretical and practical works. Grotowski comprehended the history of world theatre through the prism of the relationship between the actor and the audience.

The director perceived the collision with India's early theatrical culture and ritual tradition as a playful, parody comic nature and, on the other hand, as a deeply personal, painfully own material for creating a performance. Earlier productions based on the texts of Byron and Mayakovsky attracted Grotowski with the greedy rebellion of the main characters; he was looking for material with the romantic pathos

4. Grotowski J. Dialog z widzem (Między "zabawą" a postawą wobec rzeczywistości) // Grotowski J. Teksty zebrane. Warszawa: Wydawnictwo Krytyki Politycznej, Instytut Teatralny im. Zbigniewa Raszewskiego, Instytut im. Jerzego Grotowskiego, 2012. P. 174. of new world order. He was attracted to the problems of classical drama by the ease of transferring the characters-fighters into the context of the youth counterculture of Europe in the early 1960s. However, Kalidasa's work is very far from Grotowski's main ideas, reflected in the productions of the late 1950 s and early 1960s.

In the production of Shakuntala, the famous stage set created by stage space architect Jerzy Gurawski can be considered to be the main provocation and direct reference to the culture of hippies and youth revolutions. The untrained viewer was first of all frightened and alarmed by the constructions on which the actors played, symbolising the phallus and vagina and referring in a playful way to the texts from the Kama Sutra, which Grotowski included in the main text of Kalidasa's play. The desire to shock the viewer, knock him or her out of the comfort zone with the help of visual images became the first stage in creating a unique Eastern European space for the formation of the structure of theatrical and, at the same time, ritual performance. On the one hand, the philosophy of destruction and ridicule and, on the other hand, a timid attempt to understand and appropriate the markers of a foreign culture is most easily embodied in the conscious deconstruction of the traditional stage division into a stage and an auditorium. Grotowski strived to preserve space for the viewers and the security of a dedicated acting space using the evocative, comically played attributes of early fertility cults from all cultures worldwide. Totemic images of phallic cults and cults of motherhood seem to become the protagonists of the play of Kalidasa, in the text of which, at the level of the most subtle poetic metaphors, the rhythm and symbolism of the early rituals of life and fertility are enclosed. The director used a clear division, inherent in ritual performances, into places for viewers and a place for the ritual - the space that is cleared and illuminated for the presence of gods or demons on earth. At the very beginning of the event, the shaman, who created the structure of the ritual action, outlined the sacred space in various ways, and most often, it contained cult, totemic attributes. In Grotowski's performance, the role of such attributes was assumed by the scenery. The actor who sang and performed complex acrobatic movements with the help of his or her own corporeality and physical contact with the decorative device maintained the distance from the audience necessary for the ritual. 
In the special Rules for Viewing by the Audience, and Especially for Reviewers, created by Grotowski and Ludwig Flaschen (director and co-author of stage versions of the performances of the Theater of 13 Rows), paragraph 4 states: "We are playing the eastern theatre. More precisely: pseudo-eastern. Through conventional gestures, the way of pronouncing the text, through the creation of a whole alphabet of conventional symbols, something like a synthesis of the Eastern theatre appears (and more a parody of the usual understanding of the Eastern theatre)" ${ }^{5}$. A kind of program or even, more precisely, the instruction for watching the performance in each of the points insisted on the ironic nature of the performance or the ironic attitude to the text of Kalidasa; it is not an attempt to reconstruct an Indian action, not an attempt to stage an Indian plot in a modern European director's theatre, but a specific game with an Indian culture, which, meanwhile, awakens "ritualism" 6 .

Working on the production of Shakuntala, Grotowski defended the theoretical part of the diploma in the speciality Director at the Solsky Higher Theater School in Krakow. A short text, The Game of Shiva, short notes on the margins of Kalidasa's play, is one of the fragments. "If I were to define our stage quest with one sentence, one term, I would appeal to the myth of Shiva's dance; I would say: 'We are having fun with Shiva', 'we are playing Shiva'. It is an attempt to absorb reality in its entirety" 7 . In Grotowski's philosophy, the dance of Shiva is a constant process of creation and destruction of being; it is the "dance of INTEGRITY" 8 . Grotowski dreamt of combining all possible expressive means of theatrical culture in the production, and thus, exhaust them, reach their limit and destroy, dissipate in exaggeration and relativity. Owing to the material of the Indian play, for the first time the director very accurately formulated the desire to destroy the main theatrical model, which was established in the theatre of the second half of the 20th century; he came to an idea which was very close to the searches of Richard Schechner in his fundamental work Theory of Performance: "The theatre has more in common with competition and sport than with play or ritual" ${ }^{9}$. Grotowski acutely felt

5. Siakuntala. Reglamin Patrzenia dla Widzów, a szczególnie Recenzentów // Flaszen L. Grotowski \& Company: Źródła I wariacje. Wrocław: Instytut im. Grotowskiego, 2014. P. 49.

6. Ibid p. 49.

7. Grotowski J. Gra w Sziwę // Grotowski J. Teksty zebrane. P. 180.

8. Ibid p. 179 .

9. Shehner R. Performance Theory. Moscow: V-A-C Press, 2020. P. 35. this dependence, he realized the impossibility of returning the theatre to its ritual roots. In the process of working on the production of Shakuntala, for the first time, problems arose related to the very idea of reconstructing the ritual structure. At the beginning of his work, Grotowski simplified as much as possible, schematized the main distinguishing features of the structure of ritual action and theatrical performance. For him, the fundamental difference was the function of the viewer in theatrical and ritual forms.

Grotowski's practical experiments posed the problem not of ritual as a phenomenon belonging to a particular culture or communication model of society ${ }^{10}$ but of the emergence of a ritual structure from the purely personal experience of the creator of the action. Eugenio Barba, an Italian director and founder of the International School of Theater Anthropology, became a kind of follower of Grotowski's ideas. Talking about his internship at the 13 Rows Theater-Laboratory in a slightly ironic manner, he wrote that Grotowski, working on Shakuntala, did not even have a remote idea about the traditional acting art of India. After a trip to this country and a short stay at the school of the traditional Indian dance theatre Katakhali, Barba himself understood that it is impossible ${ }^{11}$ to create mudras, symbolic gestures with hands, without a lively touch to Indian culture. This reproach for the absence of a living touch to the cultural tradition of Indian theatre reveals as accurately as possible a working model of creating a ritual performance, according to Grotowski. For the purity of the experiment, he needed a text that carried the ritual tradition of signs in the process of its presentation on stage; however, for the European consciousness and perception, these signs remained hidden, the Polish viewer would not have been able to read the authentic Indian mudras. A personal touch to the culture of India was much more important for Grotowski. The older he became, the more often, in his articles and conversations with students, he recalled one of the first books he read in childhood, The Paths of Yogis by the English journalist P. Brunton. The events of childhood during the Second World War, hunger, illness, memories of his mother were intertwined with the first thoughts of little Grotowski about the figure of the holy fool in

10. Levi-Strauss K. Structural Anthropology. Moscow: Academicheskiy Project, 2008. P. 555.

11. Barba E. Land of Ashes and Diamonds. My Apprenticeship in Poland. Followed by 26 Letters from Jerzy Grotowski to Eugenio Barba. Aberystwyth: Black Mountain Press, Center of Performance Research, 1999. Pp. 53-77. 
different cultures of the world, about the question "Who am I?", asked by old man Sri Rama Maharishi ${ }^{12}$. For Grotowski, personal contact with Indian philosophy in childhood was a projection of "confrontation with one's own roots". The basis for the search for the latest communications in modern theatre arose not from pragmatic conclusions about the nature of ritual and theatrical performance but on the basis of personal involvement. The awakening of his own perception of the reality of the text led the director from traditional theatre to acting and ritual, devoid of markers of the theatrical tradition. Such a relationship with the dramatic text chosen for the production is close to the problem of constructing a mobile drama of ritual action, when the main text for performers and viewers is only a canvas, into which fragments from other sources are easily interwoven (in Shakuntala, not only Kamasutra was used, but also the texts of the Laws of Manu, an ancient Indian collection of religious, moral and legal prescriptions), and, more importantly, fragments of their own attitude, open play, interpretation, rethinking of the structure of the development of action, characters and their places in the plot construction. It is no coincidence that working with a costume, Grotowski used children as the creators of visual images of the performance. Seventeen years after the premiere of Shakuntala, Flaschen recalled that sketches of theatrical costumes for this production were based on children's drawings. "We had a friend who was a teacher; he asked his students to draw a Knight, a Prince, a Girl. As a result, the costumes were extremely variegated, a little primitive; there was something oriental about them. It was exactly the feeling of the young people of the East" ${ }^{13}$. A child's view became the basis for the interpretation of the text. For the director, children's naive perception of the world seemed to be an analogue of the transparency and simplicity of the plot construction of the Sanskrit drama. However, the actor and partly the viewer in this position of the child seemed to have the opportunity to perceive the plot as something excessively simple, as a fairy tale, as a myth about the "eternal paradox of love" ${ }^{14}$, as an archetypal construction.

In the ancient Indian treatise Natya Shastra, dedicated to the art of theatrical performances, in

12. Osiński Z. Polskie kontakty teatralne z orientem w XX wieku: Studia. Gdańsk: słowo/obraz terytoria, 2008. Pp. 166-167.

13. Kumiega J. The Theatre of Grotowski. London and New York: Methuen, 1985. P. 31.

14. Ibid p. 30. the descriptions of various aspects of the spectacle, precise terms and categories are given, "which include two types of success (siddhi) of the performance - divine and human, two types of stage practice - life-like (lokadharmi) and conditional (natyadharmi)" ${ }^{15}$. The interpenetration of lifelikeness and maximum conventionality became the main subject of Grotowski's search in the production of Shakuntala. "The performance can become a combination of a 'synthetic gesture', a 'danced' reality, a 'ritual' game" ${ }^{16}$. Stanislavsky's realistic theatre was rejected by the director at this stage of his search. The director did everything possible to ensure that the actors continue to be themselves, without becoming characters, always maintaining a clear distance between their own sense of open play and the role ${ }^{17}$. The way of the actor's existence in the first performances of the Theater of 13 Rows is close to Brecht's concept of alienation, to Meyerhold's biomechanical actor. Immersion in the play and simultaneous removal from the hero of the action is characteristic of the ritual techniques of shamans. The performer of the ritual dance, even in a trance state, maintains the border between himself and the entry of a spirit, a demon or divine essence ${ }^{18}$ into his body. Most often such co-presence of the divine and the human in the body and dance of a shaman is achieved with the help of a mask, doll or another sacred object. Grotowski made the work of his actors on stage as difficult as possible, using elaborate costume and make-up, oversaturated the score of the roles with acrobatic figures and bodily signs from the Indian tradition.

In his 1968 article "Theater and Ritual", Grotowski insisted that attempts to work with the ritual structure were primarily experiments with the stage and the desire to include the viewer in the process of theatrical performance ${ }^{19}$. Many researchers of the Polish experimenter's work consider this initial work with space to be a failure, a seeming projection of the

15. Lidova N. R. "Indian Theatre. At the Origins of Tradition" // Theater and Spectacular Forms of the East: From Ritual to Performance. Collection of articles. Issue. 1. Moscow: Russian University of Theater Arts - GITIS, 2012. P. 40.

16. Grotowski J. Gra w Sziwę // Grotowski J. Teksty zebrane. P. 180.

17. Bednorz Z. "Siakuntala", czyli cyrk z regulaminem // Misterium zgrozy I urzeczenia: Przedstawienia Jerzego Grotowskiego I Teatru Laboratorium. Wrocław: Instytut im. Jerzego Grotowskiego, 2006. P. 135.

18. Eliade M. Shamanism. Archaic Techniques of Ecstasy, translated from French by V. Trylis. Moscow: Academicheskiy Project, 2014. P. 399.

19. Grotowski E. "Theatre and Ritual" // From Poor Theater to Art as a Guide. P. 351. 
wrong way of "transforming the 'scene-auditorium' relationship and transforming the audience into participants, which he saw as the basis of ritual. These attempts, although interesting, failed" ${ }^{20}$. In Kalidasa's play, "there are 34 characters, as well as hermits, disciples, courtiers and the royal retinue. In the play, the role of 'society' belonged to the audience" $^{21}$. The stage space had complex architecture: the audience sat opposite each other, those who came to the performance saw both the actors in the centre of the room and the audience sitting opposite. This arrangement in space gave the observer a way of being in the production structure, similar to the way of being an actor. The viewer, observing not only the performance but also the other viewer, got the opportunity of an objective point of view; at the moment of the performance, he or she could see the reaction of others and have time to analyse it. In some moments of the performance, the light unexpectedly illuminated not the actors but the places for the audience ${ }^{22}$. The director, with the help of theatrical, expressive means, forced the viewer to take an active part in what was happening; he wanted to bring the viewer closer to the position of an accomplice of the ritual. Thus, diametrically opposed attitudes within one theatrical structure were exposed; the viewer had to remain aloof and capable of ironic analysis; however, at the same time, the director tried to create a space for the co-presence of the viewer-participant, who was inscribed in the structure of the development of the action and had to react in a certain way to the projection of integrity that arose at the moment of the actual process of creating the action, the magic dance of Shiva, creating and destroying at the same time.

From the sphere of viewer complicity, Grotowski deliberately left for the sphere of the specifics of the actor's existence in the play model, in the "ritualism" 23 or the "ritual" 24 of the ironic appropriation of the Indian manner of presentation. "It is quite possible that the detached qualities in his research work on this text, and his attempt to free the actor

20. Kosinsky D. Polish Theater. Stories. Moscow: Novoye Literaturnoye Obozrenie, 2018. P. 101.

21. Osiński Z. Grotowski i jego Laboratorium. Warszawa: Państwowy Instytut Wydawniczy, 1980. P. 82.

22. Bednorz Z. "Siakuntala", czyli cyrk z regulaminem // Misterium zgrozy I urzeczenia: Przedstawienia Jerzego Grotowskiego i Teatru Laboratorium. Wrocław: Instytut im. Jerzego Grotowskiego, 2006. P. 135

23. Siakuntala. Reglamin Patrzenia dla Widzów, a szczególnie Recenzentów // Flaszen L. Grotowski \& Company: Źródła i wariacje. P. 49.

24. Grotowski J. Gra w Sziwę // Grotowski J. Teksty zebrane. P. 180 from the overwhelming influence of literature was one of the reasons why Grotowski chose Shakuntala for the theatre production of 13 Rows" ${ }^{25}$. However, in the methods and approaches of the director, the way of denying the text and the study of the possibility of "creating a system of signs in the European theatre" 26 more and more actualised the idea of not reconstructing ritual practices, but the method of crystallising the foundations of the ritual structure in the process of creating an action. Copying and even ironic transfer of bodily signs of Indian culture on the soil of European theatre turned them into "stereotypes" and "cliches of gesture" 27. It was in the process of working on Shakuntala that Grotowski "had to introduce voice training since it is impossible to create musical signs without a special preparation" 28

The play Shakuntala was based on gestural and vocal signs, as if, even against the will of Grotowski himself, the implementation of the text of the Sanskrit drama entailed the emergence of bodily and voice training for actors in the theatrical practice of the director. Even in the ironic form of playing with oriental rituals itself, a syncretic form of the actor's existence began to appear. The ninth chapter of Natya Shastra is devoted to the description of sign language. "Hand gestures were peculiar hieroglyphssymbols of a special 'silent' language, extremely rich and diverse. Demonstrating certain combinations of fingers, the participant in the drama could express all the main 'meanings' of human communication" ${ }^{29}$. In the first half of the 20th century, cultural anthropology posed the problem of the subtle interaction of gestures and the spiritual state of a person. In 1934, M. Moss, presenting the concept of "bodily techniques", spoke of similar and different features of the simplest physical body movements that are inherent in any person in the world; however, speaking about the techniques of birth, running, sitting, eating, and many others from the point of view of physiology, i.e. unconditional corporeality of human nature, the researcher came to an unexpected conclusion about the existence of certain body positions that could create "communication

25. Kumiega J. The Theatre of Grotowski. Pp. 28-29.

26. Grotowski E. "Theatre and Ritual" // From Poor Theater to Art as a Guide. P. 112

27. Ibid p. 113

28. Ibid p. 112

29. Lidova N. R. Drama and Ritual in Ancient India. Moscow: Nauka. Vostochnaya Literatura Publishing company Vostochnaya Literatura, 1992. P. 57 
with God" ${ }^{30}$. Formulating the provisions of the new science "Anthropology of Gestures", M. Jousse refused to oppose "spirituality" and physical action ${ }^{31}$. Following Jousse and ethological theorists, a contemporary French anthropologist and culturologist, J. M. Pradier, insisted that "a gesture has a metaphysical dimension: it is a living person interacting with the cosmos" 32 . Grotowski's childhood enthusiasm for Indian philosophy and categories of Eastern culture was transformed into a purely personal selection of material for the production. Through fantasies about the bodily culture of Indian dancers and theoretical knowledge of yoga, the director made his way to a complex of bodily exercises created entirely by his imagination. And if the nature of the actor's existence in the play still bore, rather, a synthetic character, dictated by the already existing systems of non-psychological role creation, the training that took shape in the process of working on Shakuntala contained the potential for creating a syncretic actor who equally mastered the gesture sign, vocals - word, movement - the structure of the action, "all his efforts are aimed at uniting body, voice, mind and spirit" 33 .

Indian mudras paradoxically grew into the consciousness and physicality of Polish actors. The experience of the "cultural body" of Polish actors transformed the alphabet of Indian dance and turned it into comic body signs through which a more complex layer of cultural paradigms began to grow and form. A philosophy of uniting the Eastern sign and European bodily culture arose. Bodily signs came to life within the framework of the score of the ritual

30. Moss M. List of Bodily Techniques // Barba E., Savarese N. Dictionary of Theatrical Anthropology: The Secret Art of the Performer. Moscow: Artist. Rejisser. Teater, 2010. P. 227.

31. Jousse M. Études de psychologie linguistique. Le Style oral rythmique et mnémotechnique chez les Verbo-moteurs. Paris: Gabriel Beauchesne, 1925. P. 242.

32. Pradier J. M. "Flesh is Spirit: Ritual or the Problem of Action" // Religion, Ritual, Theater; Kharkiv: Gumanitarniy Center Publishing House, 2018. P. 203.

33. Shehner R. Performance Theory. P. 81. structure; the viewer immersed in the action "through a continuous process of production and interpretation of signs, which more and more conveys the essence of the world and increasingly orients the interpreting self towards this objectivity" ${ }^{34}$. Understanding of the body-sign within the framework of the performance took place at the level of the reactions of the audience themselves. Their shock from the set design, their attitude to the bright and at the same time simplified colours of costumes, the dichotomy of gesture and word, for example, a long love monologue that the actor uttered while standing on his head - all these directorial techniques allowed the viewer to be involved in the action at a symbolic level. A living sign process became the basis of a living ritual structure. One of the basic yoga asanas, Shirshasana, a headstand, continues to translate, at the level of bodily technique, one of the positions of the body, close to the divine comprehension of life. The text pronounced by the actor at this moment comes into conflict with the bodily code, if to accept the laws of perception of the European viewer; however, at the same time, it seems to become a catalyst for the very theme of the Sanskrit text. It is a story about the eternal love of mythological heroes. Thus, unexpectedly, the mockery turns into part of the ritual action. In the deconstruction of the Indian text, Grotowski found the integrity he was looking for; at the moment of destroying the Indian body, he created body signs that were close to the European perception of the eastern structure of the development of action. From dichotomies, a striving for an ideal body arose, which would become a guide in the ritual model of a new form of theatrical performance at the more mature stages of Grotowski's work, the period of poor theatre and the time of paratheatrical experiments.

34. Kon E. How Forests Think: Towards Anthropology Beyond Man, translated from English by A. Borovikova. Moscow: Ad Marginem Press, 2018. P. 70.

\section{REFERENCES}

1. Grotowski, E. 2003. "From Poor Theater to Art as a Guide", Collection of articles. Translated from Polish; introduction and notes by N. Bashinjaghyan. Moscow: Artist. Rejisser. Teater, p. 351.

2. Kon, E. 2018. How Forests Think: Towards Anthropology Beyond Man, translated from English by A. Borovikova. Moscow: Ad Marginem Press, p. 344.
3. Kosinsky, D. 2018. Polish Theater. Stories, translated from Polish by N. Nikolskaya, M. Yasinskaya; scientific ed. N. Yakubova. Moscow: Novoye Literaturnoye Obozrenie, p. 456.

4. Levi-Strauss, K. 2008. Structural Anthropology, translated from French by V. Ivanov. Moscow: Academicheskiy Project, p. 555. 
5. Lidova, N. R. 1992. Drama and Ritual in Ancient India. Moscow: Nauka. Vostochnaya Literatura Publishing company, p. 149.

6. Lidova, N. R. 2012. "Indian Theatre. At the Origins of Tradition", Theater and Spectacular Forms of the East: From Ritual to Performance. Collection of articles. Issue. 1 / Comp. D. Guseinova, E. Morozova. Moscow: Russian University of Theater Arts - GITIS, pp. 13-44.

7. Moss, M. 2010. "List of Bodily Techniques", Barba E., Savarese N. Dictionary of Theatrical Anthropology: The Secret Art of the Performer. Moscow: Artist. Rejisser. Teater, pp. 218-227.

8. Pradier, J. M. 2018. "Flesh is Spirit: Ritual or the Problem of Action", Religion, Ritual, Theater / Ed.B. Holma, B. Nielsen, K. Wedel; translated from English; Kharkiv: Gumanitarniy Center Publishing House, pp. 196-218.

9. Shehner, R. 2020. Performance Theory, translated from English by A. Aslanyan. Moscow: V-A-C Press, p. 488.

10. Eliade, M. 2014. Shamanism. Archaic Techniques of Ecstasy, translated from French by V. Trylis. Moscow: Academicheskiy Project, p. 399.

11. Barba, E. 1999. Land of Ashes and Diamonds. My Apprenticeship in Poland. Followed by 26 Letters from Jerzy Grotowski to Eugenio Barba. Translated from Ital- ian and Polish by J. Barba and E. Barba. Aberystwyth: Black Mountain Press, Center of Performance Research, p. 191.

12. Bednorz, Z. 2006. "Siakuntala", czyli cyrk z regulaminem, Misterium zgrozy I urzeczenia: Przedstawienia Jerzego Grotowskiego I Teatru Laboratorium, pod red. J. Deglera i G. Ziółkowskiego. Wrocław: Instytut im. Jerzego Grotowskiego, pp. 134-135.

13. Flaszen, L. 2014. Grotowski \& Company: Źródła I wariacje. Wrocław: Instytut im. Grotowskiego, p. 386.

14. Grotowski, J. 2012. Teksty zebrane. Warszawa: Wydawnictwo Krytyki Politycznej, Instytut Teatralny im. Zbigniewa Raszewskiego, Instytut im. Jerzego Grotowskiego, p. 1131.

15. Jousse, M. 1925. Études de psychologie linguistique. Le Style oral rythmique et mnémotechnique chez les Verbomoteurs. Paris: Gabriel Beauchesne, p. 242.

16. Kumiega, J. 1985. The Theatre of Grotowski. London and New York: Methuen, p. 290.

17. Osiński, Z. 1980. Grotowski i jego Laboratorium. Warszawa: Państwowy Instytut Wydawniczy, p. 412.

18. Osiński, Z. 2008. Polskie kontakty teatralne z orientem w XX wieku: Studia. Gdańsk: słowo/obraz terytoria, p. 317. 
Полина Михайловна Степанова

кандидат искусствоведения, доцент

профессор кафедры драматургии и киноведения

Санкт-Петербургского государственного института кино и телевидения e-mail: st-more@yandex.ru

Санкт-Петербург, Россия

ORCID 0000-0001-8410-9086

DOI: 10.36340/2071-6818-2021-17-2-124-137

\section{РЕАКТУАЛИЗАЦИЯ РИТУАЛЬНОЙ СТРУКТУРЫ В СПЕКТАКЛЕ ЕЖИ ГРОТОВСКОГО «САКУНТАЛА» КАЛИДАСЫ (1960)}

Аннотация: Знаменитый польский режиссёрэкспериментатор Ежи Гротовский внёс неоценимый вклад в развитие мирового современного театрального процесса, его поиски театрального (1959-1969) и паратеатрального (1970-1979) периодов остро поставили проблему взаимоотношений актёра и зрителя в процессе создания и восприятия спектакля или ритуала. Открытия Гротовского расширяют и углубляют предмет театра, актуализируют философию восприятия зрителемсоучастником и актёром-создателем поля совместного действа. Статья рассматривает фундаментальные основы реконструкции ритуальных структур и пространства в самом раннем творчестве польского экспериментатора. На примере спектакля «Сакунтала» по мотивам текста классической санскритской драмы Калидасы (1960) рассматриваются основные приёмы работы над новыми связями между актёром и зрителем в ходе театрального представления как ритуальной формы соучастия. Главными выразительными средствами на этом этапе работы режиссёра становятся: деконструкция сценического пространства, избавление от чёткого разделения на сцену и зрительный зал, данное построение позволяет включить зрителя в процесс театрального представления, делает его активным соучастником действия; специфический подбор материала для постановки, классический индийский текст, который одновременно вызы-

Знаменитый польский режиссёр-экспериментатор Ежи Гротовский, осмысляя итоги первого периода своего творчества, который длился десять лет с 1959 по 1969 год и включал все театральные работы постановщика, называл это время «возвращением к ритуалу» ${ }^{1}$, воссозданием «церемо-

1. Гротовский Е. Театр и ритуал // От Бедного Театра к Искусству-проводнику. М.: Артист. Режиссер. Театр, 2003. С. 100. вает иронию у режиссёра, актёров и зрителей, и вместе с тем отсылает на архетипическом уровне к прасюжету о вечной любви; использование детских рисунков в процессе создания сценических костюмов как некий момент фетишизации ритуального времени и пространства; создание уникальной телесной партитуры актёров для достижения максимального проникновения в проблематику текста и одновременно отстранение от него. Главной фигурой постановки становится актёр, который, не проникая в сценический образ на уровне психологической партитуры роли, используя способ существования, близкий театральным системам В. Мейерхольда и Б. Брехта, создаёт партитуру роли, совмещая телесные техники жизни (М. Мосс) и жест в метафизическом измерении (М. Жусс). Тело исполнителя обретает функции проводника, создаёт новый вид коммуникативной модели отношений актер - зритель, обнажает дихотомию визуального мизансценического решения и вербальной текстовой части представления. Традиционный театральный спектакль, благодаря использованию индийских знаковых систем, вступает в сложные связи с прообразом ритуальной структуры, созидаемой здесь и сейчас в живом процессе действа.

Ключевые слова: ритуальная структура, телесные техники, санскритская драма, антропология жеста, паратеатральные опыты, зритель-соучастник.

ниала участия» ${ }^{2}$, вступлением в «конфронтацию с собственными корнями» ${ }^{3}$. Выбор драматического материала для ранних спектаклей обуславливает движение режиссёра от традиционного театрального представления к совершенно новой функции паратеатральных опытов, созданных

2. Там же. С. 101.

3. Там же. С. 111. 
Гротовским в 1970-е годы, и к философии мирского ритуального действа 1980-1990-х годов. Древний индийский текст классической санскритской драмы $\mathrm{V}$ века становится уникальным переходом от работ с классическим драматургическим материалом европейского и русского театрального наследия к текстам, близким к истокам мировой театральной культуры. Первыми экспериментальными спектаклями Театра 13 рядов в небольшом польском городе Ополе были «Орфей» Ж. Кокто (1959), «Каин» Дж. Байрона (1960), «Мистериябуфф» В. Маяковского (1960). Но после постановки «Сакунталы» по мотивам текста Калидасы в репертуарной политике коллектива Гротовского произойдёт качественный перелом, и пафос возвращения к ритуалу начнёт трансформироваться в идею «конфронтации с собственными корнями». Столкновение с восточной драматической структурой становится катализатором в формировании философии поиска новой формы театрального представления, в котором зрители и актёры становятся соучастниками единого действа. Сразу после работы над воплощением текста Калидасы коллектив Театра 13 рядов начнёт этап, основанный на традиционной национальной драматургии, проникнутой польской самостью и несущей в структуре текстов народную культурную традицию. «Дзяды» А. Мицкевича (1961), «Кордиан» Ю. Словацкого (1962), «Акрополь» С. Выспяньского (1962) - именно эти спектакли сделают театр одной из самых знаменитых в мире экспериментальных площадок второй половины XX века.

Работа с индийским материалом проявляет и обнажает важнейшую для Гротовского во все периоды его творчества проблему создания единого информационного, чувственного, энергетического поля для актёра и зрителя. «Поиск театра как «диалога с публикой», поиск конкретной формы этого «диалога» ${ }^{4}$ привлекает режиссёра с самых первых его теоретических и практических работ. Гротовский постигает историю мирового театра сквозь призму отношений актёра и зрителей.

Столкновение с ранней театральной культурой и ритуальной традицией Индии воспринимается режиссёром как игровая, пародийная комическая природа, но, с другой стороны, и как глубоко

4. Grotowski J. Dialog z widzem (Między «zabawą» a postawą wobec rzeczywistości) // Grotowski J. Teksty zebrane. Warszawa: Wydawnictwo Krytyki Politycznej, Instytut Teatralny im. Zbigniewa Raszewskiego, Instytut im. Jerzego Grotowskiego, 2012. S. 174 личный, болезненно собственный материал для создания спектакля. Более ранние постановки по текстам Байрона и Маяковского привлекали Гротовского жадным бунтарством главных героев, он искал материал с романтическим пафосом нового мироустройства. Его притягивала в проблематике классической драмы лёгкость переноса персонажей-борцов в контекст молодёжной контркультуры Европы начала 1960-х годов. Но произведение Калидасы очень далеко от основных идей Гротовского, отразившихся в постановках конца 1950-х годов и начала 1960-го года.

В постановке «Сакунталы» главной провокацией и прямой отсылкой к культуре хиппи и молодёжных революций можно считать знаменитую декорационную установку, созданную архитектором сценического пространства Ежи Гуравским. Неподготовленного зрителя в первую очередь пугали и настораживали конструкции, на которых играли актёры, символизировавшие фаллос и вагину и отсылавшие в игровой форме к текстам из «Камасутры», которые были включены Гротовским в основной текст пьесы Калидасы. Желание шокировать зрителя, выбить его из зоны комфорта с помощью визуальных образов становится первым этапом в создании уникального восточноевропейского пространства для формирования структуры театрального и вместе с тем ритуального действа. Философия разрушения и насмешки, с одной стороны, и робкой попытки понять и присвоить маркеры чужой культуры - с другой, проще всего воплощается в сознательной деконструкции традиционного сценического разделения на сцену и зрительный зал. Гротовский старается сохранить места для зрителей и защищённость специального места для игры актёров, используя вызывающие комически обыгрываемые атрибуты ранних культов плодородия из всех культур мира. Тотемные изображения фаллических культов и культов материнства будто бы становятся действующими лицами самой пьесы Калидасы, в тексте которой на уровне тончайших поэтических метафор заключены ритмика и символика ранних ритуалов жизни и плодородия. Режиссёр использует свойственное ритуальным представлениям чёткое разделение на места для наблюдающих и место проведения ритуала, то пространство, которое очищено и освещено для присутствия богов или демонов на земле. Шаман, созидающий структуру ритуального действа, в самом начале события разными спо- 
собами очерчивает священное пространство, и чаще всего оно содержит культовые, тотемные атрибуты. Роль таких атрибутов в спектакле Гротовского берёт на себя декорация, и актёр поющий и исполняющий сложные акробатические движения с помощью собственной телесности и физического контакта с декорационным устройством, сохраняет необходимую для ритуала дистанцию со зрителями.

В специальных «Правилах для просмотра зрителями, а особенно для рецензентов», созданных Гротовским и Людвигом Фляшеном (завлитом и соавтором сценических версий спектаклей Театра 13 рядов) в пункте 4 указано: «Мы играем в восточный театр. Точнее: псевдовосточный. Через условные жесты, способ произнесения текста, через создание целого алфавита условных знаков возникает что-то вроде синтеза театра восточного (а более пародия на обычное понимание театра Востока)» 5 . Своеобразная программка или даже, точнее, инструкция по просмотру спектакля в каждом из пунктов настаивает на ироничной природе спектакля или ироничном отношении к тексту Калидасы, это не попытка реконструкции индийского действа, не попытка постановки индийского сюжета в современном европейском режиссёрском театре, но специфическая игра с индийской культурой, которая между тем пробуждает «обрядовость» 6

Работая над постановкой «Сакунталы», Гротовский защищает теоретическую часть диплома по специальности «Режиссёр» в Высшей театральной школе им. Л. Сольского в Кракове, одним из фрагментов является небольшой текст «Игра в Шиву», короткие заметки на полях пьесы Калидасы. «Если бы я должен был определить наши сценические поиски одним предложением, одним термином, я бы апеллировал к мифу о танце Шивы; сказал бы: «развлекаемся с Шивой», «мы играем в Шиву». В этом есть попытка впитать реальность во всей её полноте» 7 . Танец Шивы в философии Гротовского - это постоянный процесс созидания и разрушения бытия, это «танец ЦЕЛОСТНОСТИ» ${ }^{8}$. Гротовский мечтает соединить в постановке все возможные выразительные средства театральной культуры, и таким образом ис-

5. Siakuntala. Reglamin Patrzenia dla Widzów, a szczególnie Recenzentów // Flaszen L. Grotowski \& Company: Źródła I wariacje. Wrocław: Instytut im. Grotowskiego, 2014. S. 49.

6. Ibid. S. 49.

7. Grotowski J. Gra w Sziwę // Grotowski J. Teksty zebrane. S. 180.

8. Ibid. S. 179 черпать их, дойти до их предела и уничтожить, рассеять в утрированности и относительности. Благодаря материалу индийской пьесы, режиссёр впервые очень точно формулирует желание разрушения основной театральной модели, которая утвердилась в режиссёрском театре второй половины XX века, приходит к идее, максимально близкой поискам Ричарда Шехнера в его фундаментальной работе «Теория перформанса»: «У театра больше общего с соревнованиями и спортом, чем с игрой или ритуалом» ${ }^{9}$. Гротовский остро чувствует эту зависимость, он осознаёт невозможность возвращения театра к ритуальным корням. В процессе работы над постановкой «Сакунталы» впервые возникают проблемы, связанные с самой идеей реконструкции ритуальной структуры. В начале творчества Гротовский максимально упрощает, схематизирует основные отличительные черты структуры ритуального действа и театрального спектакля, для него фундаментальным отличием является функция зрителя в театральной и ритуальной формах.

Практические опыты Гротовского ставят проблему не ритуала как явления, принадлежащего некоторой культуре или коммуникационной модели общества ${ }^{10}$, а возникновения ритуальной структуры из сугубо личного опыта создателя действа. Своеобразным последователем идей Гротовского стал Эудженио Барба, итальянский режиссёр, создатель Международной школы театральной антропологии, который, рассказывая о своей стажировке в Театре-Лаборатории 13 рядов в немного ироничной манере, пишет, что Гротовский, работая над «Сакунталой», не имел даже отдалённого представления о традиционном актёрском искусстве Индии. Сам Барба после путешествия в эту страну и короткого пребывания в школе традиционного индийского танцевального театра катакхали понимал, что без живого прикосновения к индийской культуре создавать мудры, символические жесты кистями рук, невозможно ${ }^{11}$. Именно этот упрёк в отсутствии живого прикосновения к культурной традиции индийского театра и обнажает максимально точно рабочую модель создания ритуального действа по

9. Шехнер Р. Теория перформанса. М.: V-A-C Press, 2020. С. 35

10. См.: Леви-Строс К. Структурная антропология. М.: Академический Проект, 2008. 555 с.

11. Barba E. Land of Ashes and Diamonds. My Apprenticeship in Poland. Followed by 26 Letters from Jerzy Grotowski to Eugenio Barba. Aberystwyth: Black Mountain Press, Center of Performance Research, 1999. P. 53-77. 
Гротовскому. Для чистоты эксперимента ему требуется текст, который несёт в себе ритуальную традицию знаков в процессе его представления на сцене, но для европейского сознания и восприятия эти знаки остаются скрытыми, польский зритель не смог бы прочесть аутентичные индийские мудры. Намного важнее для Гротовского личное прикосновение к культуре Индии, чем старше он становится, тем чаще вспоминает в статьях и разговорах со студентами одну из первых книг, которую он прочёл в детстве, «Тропинками йогов» английского журналиста П. Брунтона. События детства во время Второй мировой войны, голод, болезнь, воспоминания о матери, переплетаются с первыми размышлениями маленького Гротовского о фигуре юродивого в разных культурах мира, о вопросе «Кто я такой?», заданном стариком Шри Рамой Махариши ${ }^{12}$. Личное прикосновение к индийской философии в детстве является для Гротовского проекцией «конфронтации с собственными корнями». Почва для поиска новейших коммуникаций в современном театре возникает не из прагматических выводов о природе ритуального и театрального действа, а на основе личной вовлеченности. Пробуждение собственного восприятия реальности текста ведёт режиссёра от традиционного театра к игре и ритуалу, лишённых маркеров именно театральной традиции. Подобные отношения с драматическим текстом, выбранным для постановки, близки проблеме конструирования подвижной драматургии ритуального действа, когда основной текст для исполнителей и наблюдающих является только канвой, в основу которой с лёгкостью вплетаются фрагменты из других источников (в «Сакунтале» использовалась не только «Камасутра», но и тексты Законов Ману, древнеиндийского сборника религиозно-моральных и правовых предписаний), но, что ещё важнее,фрагменты собственного отношения, открытой игры, трактовки, переосмысления структуры развития действия, персонажей и их мест в сюжетной конструкции. Не случайно на уровне работы с костюмом Гротовский использует в качестве создателей визуальных образов спектакля детей. Через семнадцать лет после премьеры «Сакунталы» Фляшен вспоминает, что эскизы театральных костюмов к этой постановке были выполнены на основе детских рисунков. «У нас был друг, кото-

12. $\mathrm{CM}_{\mathrm{M}}$ : Osiński Z. Polskie kontakty teatralne z orientem w XX wieku: Studia. Gdańsk: słowo/obraz terytoria, 2008. S. 166-167. рый был учителем; он попросил своих учеников нарисовать Рыцаря, Принца, Девушку. В результате костюмы были чрезвычайно пёстрыми, немного примитивными, в них было что-то восточное. Это было именно ощущение молодыми людьми Востока» ${ }^{13}$. Взгляд ребёнка стал основой для трактовки текста. Наивность детского восприятия мира кажется режиссёру аналогом прозрачности и простоты сюжетной конструкции санскритской драмы. Но актёр и отчасти зритель в этой позиции ребёнка будто бы имели возможность воспринять сюжет как что-то избыточно простое, как сказку, как миф о «вечном парадоксе любви» ${ }^{14}$, как архетипическую конструкцию.

В древнем индийском трактате «Натьяшастра», посвящённом искусству театральных представлений, в описаниях различных аспектов зрелища даны точные термины, категории, «к числу которых относятся два вида успеха (сиддхи) спектакля - божественный и человеческий, две разновидности сценической практики - жизнеподобная (локадхарми) и условная (натьядхарми)» ${ }^{15}$. Взаимопроникновение жизнеподобия и максимальной условности становится главным предметом поиска Гротовского в постановке «Сакунталы». «Спектакль может стать соединением «синтетического жеста», «танцуемой» реальности, игры «ритуальной» ${ }^{16}$. Реалистический театр К. Станиславского отвергается режиссёром на этом этапе поисков. Режиссёр делает всё возможное, чтобы актеры продолжали оставаться собой, не становясь персонажами, всегда сохраняя чёткую дистанцию между собственным ощущением открытой игры и ролью ${ }^{17}$. Способ существования актёра в первых спектаклях Театра 13 рядов близок к концепции отчуждения Брехта, к биомеханическому актёру Мейерхольда. Погружение в игру и одновременное отстранение от героя действа свойственно ритуальным техникам шаманов. Исполнитель ритуального танца даже в состоянии транса сохраняет границу между собой и вхождением в его тело духа, демона или бо-

13. Цит. по: Kumiega J. The Theatre of Grotowski. London and New York: Methuen, 1985. P. 31.

14. Ibid. P. 30.

15. Лидова Н.Р. Индийский театр у истоков традиции // Театр и зрелищные формы Востока: От ритуала к спектаклю: Сборник статей. Вып. 1. М.: Российский университет театрального искусства — ГИТИС, 2012. С. 40.

16. Grotowski J. Gra w Sziwę // Grotowski J. Teksty zebrane. S. 180.

17. Bednorz Z. «Siakuntala», czyli cyrk z regulaminem // Misterium zgrozy I urzeczenia: Przedstawienia Jerzego Grotowskiego I Teatru Laboratorium. Wrocław: Instytut im. Jerzego Grotowskiego, 2006. S. 135. 
жественной сущности ${ }^{18}$, чаще всего достигается подобное соприсутствие божественного и человеческого в теле и танце шамана с помощью маски, куклы или другого сакрального предмета. Гротовский максимально усложняет работу своих актёров на сцене, используя сложный костюм и грим, перенасыщая партитуру ролей акробатическими фигурами и телесными знаками из индийской традиции.

Гротовский в статье «Театр и ритуал» в 1968 году настаивает на том, что попытками работы с ритуальной структурой были в первую очередь эксперименты со сценической площадкой и желание включить зрителя в процесс театрального представления ${ }^{19}$. Многие исследователи творчества польского экспериментатора считают эту первоначальную работу с пространством неудачей, кажущейся проекцией неверного пути «преобразования отношений «сцена - зрительный зал» и превращения зрителей в участников, в чём видел основу ритуальности. Эти попытки, хотя и были интересны, потерпели фиаско» ${ }^{20}$. В пьесе Калидасы «34 действующих лица, а также отшельники, ученики, придворные и царская свита. В спектакле роль «общества» принадлежала зрителям» ${ }^{21}$. Сложная архитектура сценического пространства, зрители сидели друг напротив друга, пришедшие на спектакль видели и актёров в центре помещения, и зрителей, сидящих напротив. Подобное расположение в пространстве даёт наблюдающим способ существования в структуре постановки, сходный со способом существования актёра. Зритель, наблюдающий не только представление, но и другого зрителя, получает возможность объективной точки зрения, в момент самого спектакля может увидеть реакцию другого и успеть проанализировать её. В некоторые моменты представления свет неожиданно освещал не актёров, а именно места для зрителей ${ }^{22}$. Режиссёр с помощью театральных выразительных средств вынуждал наблюдающего принимать активное участие в происходящем, желал

18. См.: Элиаде М. Шаманизм. Архаические техники экстаза. М.: Академический Проект, 2014. 399 с.

19. Гротовский Е. Театр и ритуал // От Бедного Театра к Искусству-проводнику. С. 104-105.

20. Косинский Д. Польский театр. Истории. М.: Новое литературное обозрение, 2018. С. 101.

21. Osiński Z. Grotowski i jego Laboratorium. Warszawa: Państwowy Instytut Wydawniczy, 1980. S. 82.

22. Bednorz Z. «Siakuntala», czyli cyrk z regulaminem // Misterium zgrozy I urzeczenia: Przedstawienia Jerzego Grotowskiego i Teatru Laboratorium. Wrocław: Instytut im. Jerzego Grotowskiego, 2006. S. 135. приблизить смотрящего к позиции соучастника ритуала. Так обнажались диаметрально противоположные установки внутри одной театральной структуры, зритель должен был оставаться отчужденным и способным к ироническому анализу, но вместе с тем режиссёр пытался создать пространство соприсутствия зрителя-соучастника, который вписан в структуру развития действия и должен определённым образом реагировать на проекцию целостности, возникающую в момент реального процесса создания действа, магического танца Шивы, созидающего и разрушающего одновременно.

Из сферы зрительского соучастия Гротовский сознательно уходит в сферу специфики актёрского существования в игровой модели, в «обрядовости» ${ }^{23}$ или в «ритуальности» ${ }^{24}$ иронического присвоения индийской манеры представления. «Вполне возможно, что одной из причин, по которой Гротовский выбрал «Сакунталу» для постановки в Театре 13 рядов, были отстранённые качества в его исследовательской работе над этим текстом, и его попытка освободить актёра от подавляющего влияния литературы» ${ }^{25}$. Но путь отрицания текста и исследование возможности «создания системы знаков в европейском театре» ${ }^{26}$ всё больше актуализируют в приёмах и подходах режиссёра идею не реконструкции ритуальных практик, а метод кристаллизации основ ритуальной структуры в процессе создания действа. Копирование и даже иронический перенос телесных знаков индийской культуры на почву европейского театра превращал их в «стереотипы» и «штампы жеста» ${ }^{27}$, именно в процессе работы над «Сакунталой» Гротовскому «пришлось ввести голосовой тренинг, так как невозможно создавать музыкальные знаки, не обладая специальной подготовкой» 28.

Спектакль «Сакунтала» был построен на жестикуляционных и вокальных знаках, будто бы даже помимо воли самого Гротовского реализация текста санскритской драмы повлекла за собой возникновение в театральной практике режиссёра телесных и голосовых тренингов для

23. Siakuntala. Reglamin Patrzenia dla Widzów, a szczególnie Recenzentów // Flaszen L. Grotowski \& Company: Źródła i wariacje. S. 49.

24. Grotowski J. Gra w Sziwę // Grotowski J. Teksty zebrane. S. 180.

25. Kumiega J. The Theatre of Grotowski. P. 28-29.

26. Гротовский Е. Театр и ритуал // От Бедного Театра к Искусству-проводнику. С. 112

27. Там же. С. 113.

28. Там же. С. 112. 
актёров, даже в иронической форме игры с восточным ритуалом сама собой стала возникать синкретическая форма существования актёра. Девятая глава «Натьяшастры» посвящена описанию языка жестов. «Жесты рук представляли собой своеобразные иероглифы-символы особого «немого» языка, чрезвычайно богатого и разнопланового. Демонстрируя те или иные комбинации пальцев, участник драмы мог выразить все основные «смыслы» человеческого общения» ${ }^{29}$. Культурная антропология ещё в первой половине XX века поставила проблему тонкого взаимодействия жестов и духовного состояния человека. М. Мосс в 1934 году, представляя концепцию «телесных техник», говорит о схожих и различных чертах простейших физических движений тела, которые присущи любому человеку в мире, но рассуждая о техниках рождения, бега, сидения, принятия пищи и многих других именно с точки зрения физиологии, т.е. безусловной телесности человеческой природы, исследователь приходит к неожиданному выводу о существовании некоторых положений тела, способных создать «коммуникацию с Богом» ${ }^{30}$. М. Жусс, формулируя положения новой науки «Антропологии жестов», отказывается от противопоставления «духовности» и физического действия ${ }^{31}$. Современный французский антрополог и культуролог Ж.-М. Прадье вслед за Жуссом и теоретиками этологами настаивает, что «жест имеет метафизическое измерение: это живой человек, взаимодействующий с космосом» ${ }^{32}$. Детская увлечённость Гротовского индийской философией и категориями восточной культуры трансформируется в сугубо личный отбор материала для постановки. Сквозь фантазии о телесной культуре индийских танцовщиков и теоретические знания йоги режиссёр продирается к созданному полностью собственным воображением комплексу телесных упражнений. И если природа существования актёра в спектакле всё ещё несёт, скорее, характер синтетический, продиктованный уже существующими системами

29. Лидова Н.Р. Драма и ритуал в древней Индии. М.: Наука. Издательская фирма «Восточная литература», 1992. С. 57.

30. Мосс М. Перечень телесных техник // Барба Э., Саварезе Н. Словарь театральной антропологии: Тайное искусство исполнителя. М.: Артист. Режиссёр. Театр, 2010. С. 227.

31. См.: Jousse M. Études de psychologie linguistique. Le Style oral rythmique et mnémotechnique chez les Verbo-moteurs. Paris: Gabriel Beauchesne, 1925. 242 p.

32. Прадье Ж.-М. Плоть есть дух: Ритуал или проблема действия // Религия, ритуал, театр. Харьков: изд-во «Гуманитарный Центр», 2018. С. 203. непсихологического создания роли, то тренинги, сформировавшиеся в процессе работы над «Сакунталой», содержат в себе потенцию к созданию синкретического актёра, владеющего в равной степени жестом-знаком, вокалом-словом, движением-структурой действа, «все его усилия направлены на то, чтобы объединить тело, голос, разум и дух» ${ }^{33}$.

Индийские мудры парадоксальным образом врастают в сознание и в саму телесность польских актёров, опыт «культурного тела» польских актёров трансформирует алфавит индийского танца и превращает его в комические тела-знаки, сквозь которые начинает прорастать и формироваться более сложный пласт культурных парадигм. Возникает философия соединения восточного знака и европейской телесной культуры. Телесные знаки оживают в рамках партитуры ритуальной структуры, зритель погружается в действо «через непрерывный процесс производства и интерпретации знаков, который всё лучше передает суть мира и всё чаще ориентирует интерпретирующую самость на эту предметность» ${ }^{34}$. Осмысление тела-знака в рамках спектакля происходит на уровне самих реакций зрителей. Их шок от декорационного решения, их отношение к ярким и вместе с тем упрощённым краскам костюмов, дихотомия жеста и слова, например, длинный любовный монолог, который актёр произносил стоя на голове, - все эти режиссёрские приёмы позволяют зрителю включаться в действо на символическом уровне. Живой знаковый процесс становится основой живой ритуальной структуры. Одна из базовых асан йоги, Ширшасана, стойка на голове, продолжает транслировать на уровне телесной техники одно из положений тела, близкое к божественному осмыслению бытия. Текст, произносимый актёром в этот момент, вступает в конфликт с телесным кодом, если принять законы восприятия европейского зрителя, но вместе с тем, будто бы становится катализатором самой проблематики санскритского текста. Это история о вечной любви мифологических героев. Так неожиданным образом насмешка превращается в часть ритуального действа. Гротовский обретает в деконструкции индийского текста искомую им целостность, разрушая индийское тело, он в этот момент создает тела-знаки, близкие европейско-

33. Шехнер Р. Теория перформанса. С. 81.

34. Кон Э. Как мыслят леса: к антропологии по ту сторону человека. М.: Ад Маргинем Пресс, 2018. С. 70. 
му восприятию восточной структуры развития действия. Из дихотомий возникает стремление к идеальному телу, которое станет проводником в ритуальной модели новой формы театрального действа на более зрелых этапах работы Гротовского, период бедного театра и время паратеатральных опытов.

\section{БИБЛИОГРАФИЯ}

1. Гротовский Е. От Бедного Театра к Искусствупроводнику: Сб. ст. / Пер. с пол., вступ. ст. и примеч. Н.3. Башинджагян. - М.: Артист. Режиссёр. Театр, 2003. - 351 c.

2. Кон Э. Как мыслят леса: к антропологии по ту сторону человека / Эдуардо Кон; пер. с англ. А. Боровикова. - М.: Ад Маргинем Пресс, 2018. - 344 с.

3. Косинский Д. Польский театр. Истории / Дариуш Косинский; пер. с польского Н. Никольской, М. Ясинской; науч. ред. Н. Якубова. - М.: Новое литературное обозрение, 2018. - 456 с

4. Леви-Строс К. Структурная антропология / Пер. с фр. Вяч. Вс. Иванова. - М.: Академический Проект, 2008. - 555 c.

5. Лидова Н. Р. Драма и ритуал в древней Индии. - М.: Наука. Издательская фирма «Восточная литература», 1992. - 149 с.

6. Лидова Н.Р. Индийский театр. у истоков традиции // Театр и зрелищные формы Востока: От ритуала к спектаклю: Сборник статей. - Вып. 1 / Сост. Д.А. Гусейнова, Е.Б. Морозова.- М.: Российский университет театрального искусства - ГИТИС, 2012. - C. 13-44.

7. Мосс М. Перечень телесных техник // Барба Э., Саварезе Н. Словарь театральной антропологии: Тайное искусство исполнителя.-М.: Артист. Режиссёр. Театр, 2010.- С. 218-227.

8. Прадье Ж.-М. Плоть есть дух: Ритуал или проблема действия // Религия, ритуал, театр / Под ред. Б. Холма, Б.Ф. Нилсена, К. Ведель; пер. с англ. - Харьков: изд-во «Гуманитарный Центр», 2018. - С. 196-218.

9. Шехнер Р. Теория перформанса / Ричард Шехнер. Пер. с англ. А. Асланян. - М.: V-A-C Press, 2020.488 c.
10. Элиаде М. Шаманизм. Архаические техники экстаза / Пер. с фр. В. Трылис. - М.: Академический Проект, 2014. - 399 c.

11. Barba E. Land of Ashes and Diamonds. My Apprenticeship in Poland. Followed by 26 Letters from Jerzy Grotowski to Eugenio Barba / trans. from Italian and Polish by J. Barba and E. Barba. - Aberystwyth: Black Mountain Press, Center of Performance Research, 1999. - $191 \mathrm{p}$.

12. Bednorz Z. «Siakuntala», czyli cyrk z regulaminem // Misterium zgrozy I urzeczenia: Przedstawienia Jerzego Grotowskiego I Teatru Laboratorium / pod red. J. Deglera i G. Ziółkowskiego. - Wrocław: Instytut im. Jerzego Grotowskiego, 2006. - S. 134-135.

13. Flaszen L. Grotowski \& Company: Źródła I wariacje / Ludwik Flaszen. - Wrocław: Instytut im. Grotowskiego, 2014. - 386 s.

14. Grotowski J. Teksty zebrane / Jerzy Grotowski.Warszawa: Wydawnictwo Krytyki Politycznej, Instytut Teatralny im. Zbigniewa Raszewskiego, Instytut im. Jerzego Grotowskiego, 2012. - 1131 s.

15. Jousse M. Études de psychologie linguistique. Le Style oral rythmique et mnémotechnique chez les Verbomoteurs / Marcel Jousse. - Paris: Gabriel Beauchesne, 1925. - $242 \mathrm{p}$.

16. Kumiega J. The Theatre of Grotowski / Jenifer Kumiega. — London and New York: Methuen, 1985. $290 \mathrm{p}$.

17. Osiński Z. Grotowski i jego Laboratorium / Zbigniew Osiński. - Warszawa: Państwowy Instytut Wydawniczy, 1980. - $412 \mathrm{~s}$.

18. Osiński Z. Polskie kontakty teatralne z orientem w XX wieku: Studia / Zbigniew Osiński. - Gdańsk: słowo/ obraz terytoria, 2008. - $317 \mathrm{~s}$. 